\title{
Treatment of Hailey-Hailey Disease of the vulva: a retrospective case series
}

\author{
Avery M. Whitis, ${ }^{1}$ Diane Elas,${ }^{2}$ Karla Solheim, ${ }^{3}$ Colleen K. Stockdale ${ }^{2}$
}

Keywords: Hailey-Hailey Disease, familial benign chronic pemphigus, vulva

\begin{abstract}
Background: Hailey-Hailey disease (familial benign chronic pemphigus) of the vulva is a rare autosomal dominant dermatosis characterized by malformation of desmosomes and bullae, particularly in intertriginous areas.

Cases: We reviewed the cases of 5 women followed at a single academic institution over a period of 17 years. Of the 5 patients, 4 carried a diagnosis of Hailey-Hailey at the time of presentation to our institution, and one was diagnosed on biopsy. 3 were members of a family group. Initial treatment of choice was a topical steroid (betamethasone in 3, fluocinonide and hydrocortisone in 1 each), vulvar skin guidelines, tepid soaks, a skin protectant (A\&D ointment, zinc oxide) and additional treatment (crotamiton in 1, clotrimazole in 2, and Polysporin in 1). Final treatment regimens in 3 patients followed long term were zinc oxide/A\&D and betamethasone-clotrimazole ointment in all 3 , nystatin-triamcinolone ointment in 2 , oral minocycline in 1, oral fluconazole prn in 1, and topical tacrolimus in 1. Treatment courses were complicated by superimposed fungal infections, superimposed bacterial infections, and lichen simplex chronicus flares. These were treated with antifungals, topical clindamycin and
\end{abstract}

metronidazole, and steroid-antifungal bursts, respectively. Three of five patients followed long term achieved successful remission with occasional flares.

Discussion: Treatment of Hailey-Hailey disease must be tailored to the individual patient. Adherence to vulvar skin care guidelines is critical for the remission of Hailey-Hailey disease. Treatment is long-term and may be complicated by episodes of fungal and bacterial superinfection and lichen simplex chronicus.

${ }^{1}$ University of lowa Carver College of Medicine, lowa City, lowa

${ }^{2}$ University of lowa Hospitals and Clinics, Department of Obstetrics and Gynecology, Iowa City, lowa

${ }^{3}$ Partners in Obstetrics and Gynecology, Waterloo, IA

\section{Background}

Hailey-Hailey disease (HHD) (familial benign chronic pemphigus) is a rare autosomal dominant intraepidermal blistering disorder first described by the Hailey brothers in $1939 .^{1}$ Onset is in the

Please cite this paper as: Whitis AM, Diane Elas D, Karla Solheim K, Stockdale CK. Treatment of Hailey-Hailey Disease of the vulva: a retrospective case series. Proc Obstet Gynecol. 2016;6(2): Article 2 [ 8 p.]. Available from: http://ir.uiowa.edu/pog/ Free full text article.

Corresponding author: Avery M. Whitis, University of lowa Carver College of Medicine, lowa City, lowa. Email: avery-whitis@uiowa.edu

Financial Disclosure: The authors report no conflict of interest.

Received: 25 February 2016; accepted 1 June 2016; POG in Press, 8 June 2016.

Copyright: (c) 2016 Whitis et al. This is an open-access article distributed under the terms of the Creative Commons Attribution License, which permits unrestricted use, distribution, and reproduction in any medium, provided the original author and source are credited. 
3rd to 4th decade and affects males and females equally. Family history is positive in $70 \%$ of cases. ${ }^{2}$

HHD lesions are characterized as recurrent, small blisters and crusted erosions on an erythematous base with a predilection for friction areas (nape of neck, axillae, submammary regions, genitocrural, perianal, and intergluteal clefts, antecubital and popliteal fossae ${ }^{3}$ ). Solitary involvement of the vulva is rare. ${ }^{4}$ The lesions are first described as blisters, which then turn to thickened red plaques with linear fissures that can exhibit crusting, scaling, and hypertrophic growths. ${ }^{3}$ The disease has also been described to clinically present as leukoplakia, condyloma, lichenified white papules, or syringoma. ${ }^{4}$ The symptoms are worsened by increased sweating/moisture in the summer and obesity. ${ }^{5}$ Approximately $70 \%$ of patients also have longitudinal white bands present in fingernails. ${ }^{6}$

Diagnosis is indicated by chronicity of lesions, resistance to treatment, presence of similar lesions in other areas (nape of neck, axillae), presence of longitudinal white bands in the fingernails, and a positive family history. ${ }^{7}$

$\mathrm{HHD}$ is due to a mutation in the ATP2C1 gene on chromosome 3 , which codes for a calcium pump of the Golgi apparatus in keratinocytes. This mutation causes loss of intraepidermal coherence and breakdown of intercellular contacts between the desmosomal proteins and tonofilaments. ${ }^{8,9}$ Histologic specimen often shows dyskeratotic cells with acantholysis that lack epidermal hyperplasia or hyperkeratosis. ${ }^{7}$

The differential diagnosis of HaileyHailey Disease includes tinea cruris, eczema, psoriasis, candidiasis, herpes simplex virus, atopic dermatitis, lichen simplex, seborrheic dermatitis, Darier's disease, pemphigus, and carcinoma of the vulva. ${ }^{10,11,12}$

Treatment options from a review of the literature are varied and include methods of moisture reduction (antiperspirant, weight loss, gauze pads, powder), antibiotics, antifungal creams, steroids (oral, topical, or injection), botulinum toxin injections, tacrolimus, retinoids, dapsone, methotrexate, and topical 5-Fluorouracil cream. 5,6,10,13,14 More invasive treatment options include carbon dioxide laser therapy, photodynamic therapy, dermabrasion, excision, and split thickness skin grafting. ${ }^{6,15}$ These modes of treatment require several weeks to months of painful healing, but in some cases have been shown to provide definitive resolution of symptoms.

In this report we detail the cases of 5 women with Hailey-Hailey disease of the vulva and the varied treatment regimens successful in their care.

\section{Cases}

Patient 1: A 47 y.o presented to the Vulvar-Vaginal Disease (VVD) clinic with a previous diagnosis of Hailey-Hailey disease and a positive family history. She endorsed burning with urination and constant vulvar itching. On physical exam she had erythema, hyperkeratosis, and skin changes consistent with HHD on the vulva, groin, 
and mons pubis (Figure 1). Initial treatment was vulvar skin care guidelines, Zeasorb ${ }^{\circledR}$ powder (Stiefel Laboratories, Inc. North Caroline), A\&D ointment, crotamiton cream, and topical betamethasone. Flares were controlled with oral doxycycline and clobetasol cream. Complications included vaginal yeast infections treated with oral fluconazole and econazole cream, as well as secondary bacterial infections treated with doxycycline. She preferred to see her local physician due to travel time and was lost to follow up.

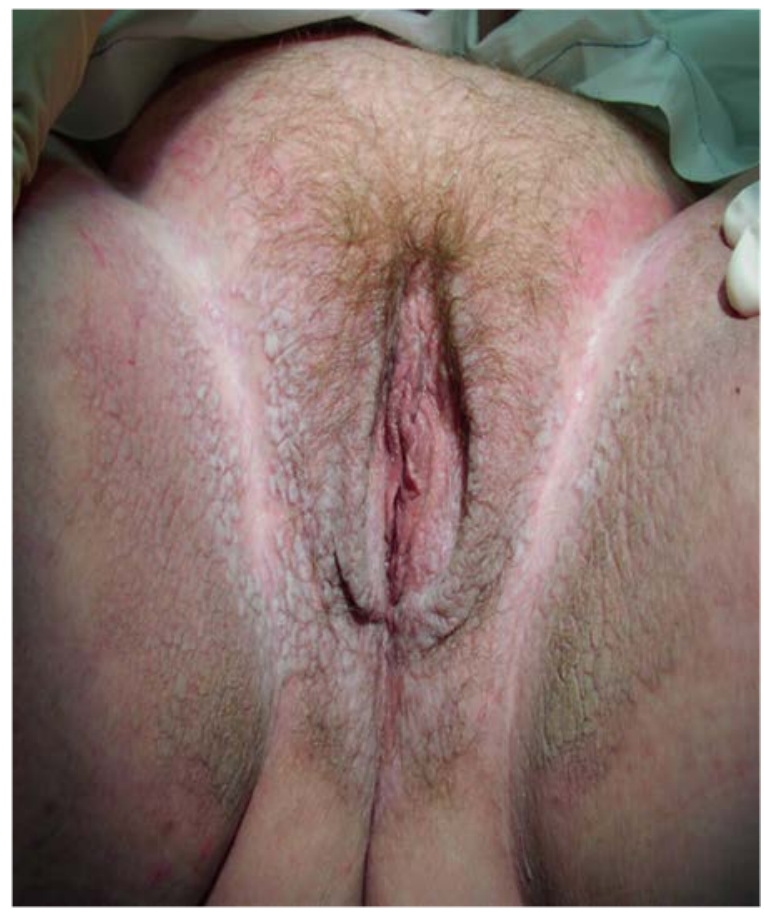

Figure 1: HHD affected skin of the vulva, mons pubis, and groin of Patient 1.

Patient 2: A 39 y.o presented to the VVD clinic for evaluation of suspected condyloma. On exam she had a raised, hyperpigmented, hyperkeratotic plaque with mild erosions and a macerated appearance around the border on her perineum. She also had plaques on the sides of her neck with erosions and hyperkeratosis. She reported the lesions had been present since age 13 and her father had similar skin changes in the same distribution. A punch biopsy was taken of the perineal lesion and showed acantholysis and dyskeratosis consistent with HHD. Initial treatment consisted of vulvar skin care guidelines, topical clindamycin lotion, and oral doxycycline. Complications included secondary yeast infections treated with fluconazole. Patient preferred to follow with dermatology, who recommended hydrocortisone ointment and Polysporin. She ultimately passed away due to unrelated causes.

Patient 3: A 30 y.o presented to the VVD clinic with a preexisting diagnosis of HHD. She had two sisters (patients 4 and 5 in this study) who also suffered from the disease. She endorsed significant rectal itching. Physical exam showed skin changes consistent with HHD in the perianal region. Initial therapy included vulvar skin care guidelines, A\&D ointment, tepid soaks, and betamethasone-clotrimazole cream. She achieved good control after 1 month of this regimen and thereafter only used the steroid cream for flares that occurred 1 week prior to each menstrual period. Complications of her disease course included lichen simplex chronicus flares. She achieved excellent and long lasting control with a final treatment regimen consisting of betamethasone-clotrimazole cream and nystatin-triamcinolone ointment only used during flares, as well as zinc oxide ointment, tepid soaks, and strict vulvar skin care guidelines. 
Patient 4: A 35 y.o (sister of patients 3 and 5) presented to the VVD clinic with a preexisting diagnosis of HHD. She complained of itching, burning with urination, pain with walking and intercourse, and thick, white discharge. Physical exam showed erythema and severe hyperkeratosis in the vulvar area with patches of lichen simplex chronicus and changes consistent with HHD. Initial treatment consisted of tepid soaks, A\&D ointment, vulvar skin care guidelines, and topical fluocinonide ointment. She also had a few axillary lesions, treated with topical metronidazole. Use of the fluocinonide was ultimately discontinued due to development of a rash. She instead trialed oral doxycycline and topical clindamycin cream for exacerbations. She still had residual itching with this regimen, and so tried multiple different topical treatments including nystatin-triamcinolone ointment, hydrocortisone valerate ointment, betamethasone-clotrimazole cream, and tacrolimus $0.1 \%$ ointment. Complications during her disease course included vaginal yeast infections treated with fluconazole, and axillary striae from chronic steroid use. Her final treatment regimen consisted of oral minocycline and topical betamethasoneclotrimazole cream for flares plus topical tacrolimus $\quad 0.1 \%$ ointment for maintenance therapy. This regimen provided excellent control of her HHD.

Patient 5: A 37 y.o (sister of patients 3 and 4) presented to the VVD clinic with a preexisting diagnosis of HHD. She complained of daily burning, itching, and pain in the vulvar and perianal area, as well as thick yellow/green vaginal discharge. She had axillary and vulvar lesions consistent with HHD (Figures 2 and 3).

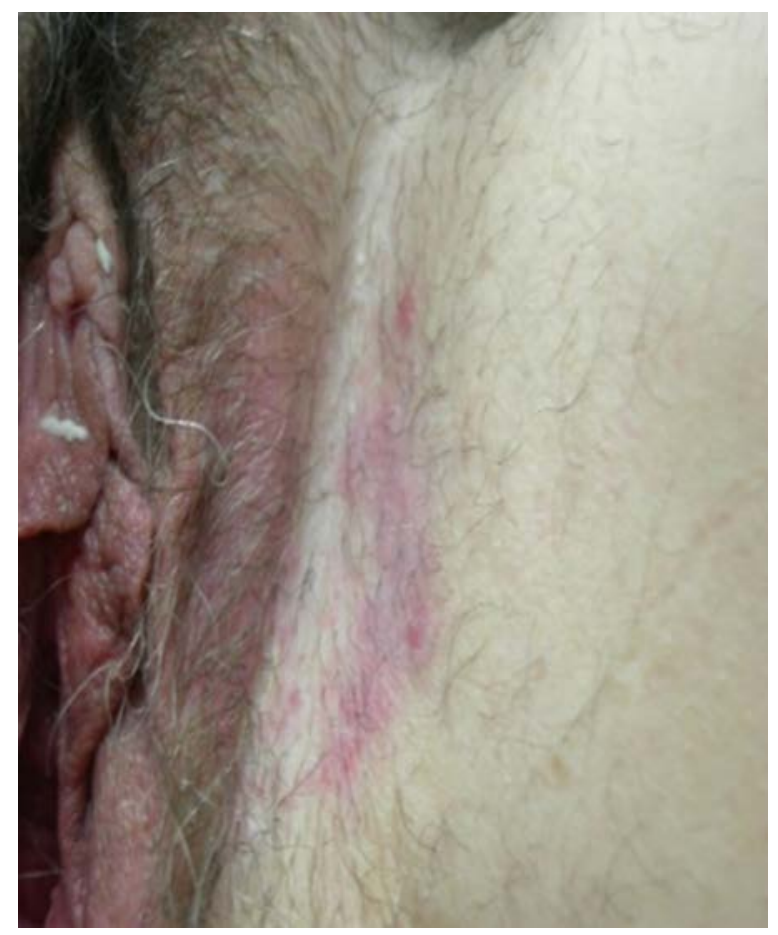

Figure 2: HHD lesion left inner thigh pre-treatment Patient 5

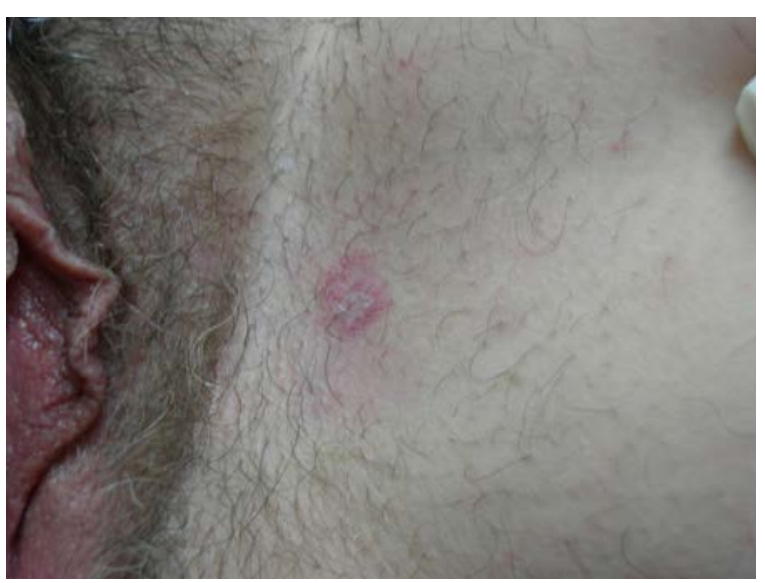

Figure 3: Lesion in left inner thigh post treatment Patient 5

Her initial treatment consisted of vulvar skin care guidelines, A\&D ointment, 
tepid soaks, and topical betamethasoneclotrimazole. She continued to have residual symptomatic flares, so nystatintriamcinolone cream was added and different steroid ointments were trialed, including triamcinolone, hydrocortisonepramoxine ointment, fluocinonide ointment, clobetasol, betamethasoneclotrimazole cream and betamethasone valerate ointment. She also received cortisol injections in the axillary regions resulting in good control of axillary disease. Complications included a clitoral abscess, which was drained and treated with bacitracin ointment, abnormal vaginal flora treated with clindamycin vaginal cream, vaginal yeast infections treated with nystatin- triamcinolone ointment and oral fluconazole, and exacerbations of lichen simplex chronicus. Her final treatment regimen consisted of betamethasoneclotrimazole cream for HHD exacerbations, nystatin-triamcinolone ointment plus fluconazole for intermittent vaginal yeast infections, vulvar skin care guidelines, and zinc oxide cream.

\section{Discussion}

The cases presented detail the varied treatments of Hailey-Hailey disease in 5 different individuals (See Table 1). Treatment goals for the 5 patients were symptom remission as well as minimization of social and functional handicaps.

Table 1

\begin{tabular}{|c|c|c|c|c|}
\hline Patient & $\begin{array}{l}\text { Preexisting } \\
\text { Diagnosis }\end{array}$ & Initial Steroid & Final Steroid & Additional Treatment \\
\hline 1 & HHD & Betamethasone & N/A & $\begin{array}{l}\text { Crotamiton, } \\
\text { oral doxycycline, } \\
\text { fluconazole }\end{array}$ \\
\hline 2 & Condyloma & Hydrocortisone & N/A & $\begin{array}{l}\text { Topical clindamycin, } \\
\text { polysporin oral doxycycline, } \\
\text { fluconazole }\end{array}$ \\
\hline 3 & HHD & $\begin{array}{l}\text { betamethasone- } \\
\text { clotrimazole }\end{array}$ & $\begin{array}{l}\text { betamethasone- } \\
\text { clotrimazole }\end{array}$ & Nystatin/ triamcinolone \\
\hline 4 & HHD & fluocinonide & $\begin{array}{l}\text { betamethasone- } \\
\text { clotrimazole }\end{array}$ & $\begin{array}{l}\text { Oral minocycline, } \\
\text { topical tacrolimus }\end{array}$ \\
\hline 5 & HHD & $\begin{array}{l}\text { betamethasone- } \\
\text { clotrimazole }\end{array}$ & $\begin{array}{l}\text { betamethasone- } \\
\text { clotrimazole }\end{array}$ & $\begin{array}{l}\text { Nystatin/ triamcinolone, } \\
\text { oral fluconazole prn }\end{array}$ \\
\hline
\end{tabular}

Some aspects of treatment were similar for all 5 patients, most notable being the need for skin protection and adherence to strict vulvar skin care guidelines to minimize friction, heat, and moisture, as these can induce flares. However, many aspects of the treatment had to be tailored to the individual patient. Use of steroid differed between individuals depending on potency required to adequately manage disease flares, and use of antibiotics also depended on clinical symptoms of the patient. This is a trend that has been reported in the literature. In a retrospective study of 58 individuals with Hailey-Hailey disease, $86 \%$ found topical steroid/antibiotic combinations to be effective at 
managing the disease. ${ }^{16}$ However, multiple potencies were used among different patients ranging from milder (hydrocortisone) to ultra potent (clobetasol) preparations, with 2 patients requiring oral prednisone. Only $43 \%$ used oral antibiotics and found them helpful. ${ }^{16}$ These results mirror the variability in treatment found among our patients.

Complications of Hailey-Hailey Disease experienced by our patients included episodes of superimposed fungal and bacterial infections as well as lichen simplex chronicus flares. These were treated with antifungals, topical clindamycin and metronidazole, oral doxycycline or minocycline, and steroidantifungal bursts. Another complication is the rare occurrence of squamous cell carcinoma in Hailey-Hailey affected skin, ${ }^{17,18,19}$ which was not experienced by any of our 5 patients. These complications, and the relapsing and remitting nature of the disease, underlie the importance of regular follow up.

One new treatment option for HaileyHailey disease that has been increasing in popularity is the chemo-denervation of sweat glands by regional injection of botulinum toxin to decrease sweat, moisture, and friction in affected areas. Multiple case reports have shown complete remission expected to last 612 months with multiple doses of botulinum toxin type $A^{20,21}$ This treatment option is attractive because it decreases the use of systemic and topical corticosteroids and minimizes their respective side effect profiles. However, it was not feasible for our patients due to high cost and lack of insurance coverage.

\section{Conclusion}

Treatment of Hailey-Hailey disease must be tailored to the individual patient. Adherence to vulvar skin care guidelines is critical for the remission of HaileyHailey disease. Treatment is long-term and may be complicated by episodes of fungal and bacterial superinfection and lichen simplex chronicus.

\section{References}

1. Hailey $H$, Hailey $H$. Familial Benign Chronic Pemphigus. Arch Derm Syphilol. $\quad 1939 ; 39(4): 679-685$. http://dx.doi.org/10.1001/archderm.1939 .01480220064005

2. Michel B. "Familial benign chronic pemphigus" by Hailey and Hailey, April 1939. Commentary: Hailey-Hailey disease, familial benign chronic pemphigus. Arch Dermatol. 1982 Oct;118(10):774-83.

http://dx.doi.org/10.1001/archderm.118. 10.774 PubMed PMID: 6753757.

3. Fitzpatrick T, Johnson R, Wolff K. Color atlas and synopsis of clinical dermatology: common and serious diseases. 4th ed. New York: McGrawHill, Medical Pub. Division; 2001. p. 92.

4. Wieselthier JS, Pincus SH. HaileyHailey disease of the vulva. Arch Dermatol. 1993 Oct;129(10):1344-5. http://dx.doi.org/10.1001/archderm.1993 .01680310116027 PubMed PMID: 8215508.

5. Lynch PJ, Edwards L. Genital dermatology. New York: Churchill Livingstone; 1994. p. 44-46.

6. Habif TP. Clinical dermatology: a color guide to diagnosis and therapy. 5th ed. Edinburgh: Mosby; 2010. p. 520-21. 
7. Hewitt J, Pelisse M, Paniel BJ. Diseases of the Vulva. London ; New York: McGraw-Hill Book; 1991. p. 124-25.

8. Wolf R, Oumeish OY, Parish LC. Intertriginous eruption. Clin Dermatol. 2011 Mar-Apr;29(2):173-9. http://dx.doi.org/10.1016/i.clindermatol.2 010.09.009 PubMed PMID: 21396557.

9. Kellermayer R. Hailey-Hailey disease from a clinical perspective. Cell Calcium. 2008 Feb;43(2):105-6. Epub 2007 Aug 17.

http://dx.doi.org/10.1016/j.ceca.2007.06. 005 PubMed PMID: 17707506.

10. Erosive and vesiculobullous diseases, Chapter 9. In: Edwards L, Lynch PJ. Genital dermatology atlas. Philadelphia, PA: Lippincott Williams \& Wilkins; 2011. p. $142-44$

11. Edwards L, Lynch P. Vulvar dermatoses: the eczematous diseases, Chapter 18. In: Black M, AmbrosRudolph C, editors. Obstetric and Gynecologic Dermatology. 2d. ed. London: Mosby, 2002. p. 190-92.

12. Dittmer CJ, Hornemann A, Rose C, Diedrich K, Thill M. Successful laser therapy of a papular acantholytic dyskeratosis of the vulva: case report and review of literature. Arch Gynecol Obstet. $2010 \quad$ Apr;281(4):723-5. http://dx.doi.org/10.1007/s00404-0091313-8 Epub 2009 Dec 15. PubMed PMID: 20012979.

13. Rabeni EJ, Cunningham NM. Effective treatment of Hailey-Hailey disease with topical tacrolimus. J Am Acad Dermatol. 2002 Nov;47(5):797-8. http://dx.doi.org/10.1067/mid.2002.1262 17 PubMed PMID: 12399782.

14. Lodha S, Cusack C, Chung C. HaileyHailey disease successfully treated with topical 5-fluorouracil. [poster P2007] J Am Acad Dermatol. 2011;64(2 Suppl 1): AB85. 64.2 (2011).
15. Collet Villette AM, Richard MA, Fourquet F, Monestier S, Gaudy C, Bonerandi JJ, Grob JJ. [Treatment of Hailey-Hailey disease with carbon dioxide laser vaporization]. Ann Dermatol Venereol. 2005 Aug-Sep;132(8-9 Pt 1):637-40. French. http://dx.doi.org/10.1016/S01519638(05)79410-2 PubMed PMID: 16230912.

16. Burge SM. Hailey-Hailey disease: the clinical features, response to treatment and prognosis. $\mathrm{Br} \mathrm{J}$ Dermatol. 1992 Mar;126(3):275-82. http://dx.doi.org/10.1111/j.13652133.1992.tb00658.x PubMed PMID: 1554604.

17. von Felbert $V$, Hampl M, Talhari C, Engers R, Megahed M. Squamous cell carcinoma arising from a localized vulval lesion of Hailey-Hailey disease after tacrolimus therapy. Am J Obstet Gynecol. $2010 \quad$ Sep;203(3):e5-7. http://dx.doi.org/10.1016/j.ajog.2010.06. 041 PubMed PMID: 20816142.

18. Cockayne SE, RassI DM, Thomas SE. Squamous cell carcinoma arising in Hailey-Hailey disease of the vulva. $\mathrm{Br} \mathrm{J}$ Dermatol. 2000 Mar;142(3):540-2. http://dx.doi.org/10.1046/j.13652133.2000.03374.x PubMed PMID: 10735968.

19. Holst VA, Fair KP, Wilson BB, Patterson JW. Squamous cell carcinoma arising in Hailey-Hailey disease. J Am Acad Dermatol. 2000 Aug;43(2 Pt 2):368-71. http://dx.doi.org/10.1067/mjd.2000.1005 42 PubMed PMID: 10901726.

20. Bessa GR, Grazziotin TC, Manzoni AP, Weber MB, Bonamigo RR. Hailey-Hailey disease treatment with Botulinum toxin type A. An Bras Dermatol. 2010 SepOct;85(5):717-22. http://dx.doi.org/10.1590/S036505962010000500021 PubMed PMID: 21152802 . 
21. Lapiere JC, Hirsh A, Gordon KB, Cook $B$, Montalvo A. Botulinum toxin type $A$ for the treatment of axillary HaileyHailey disease. Dermatol Surg. 2000 Apr;26(4):371-4.

http://dx.doi.org/10.1046/j.15244725.2000.99278.x PubMed PMID: 10759827. 